\title{
Reindeer Herding and History in the Mountains of Southern Sápmi
}

\author{
Britta Wennstedt Edvinger
}

\begin{abstract}
During the summers of 1998-2000 four Saami villages in southern Sápmi carried out a survey of traditional reindeer herding sites. Reindeer herding of today engages a small Saami minority, but the reindeer herders are important as bearers of Saami culture and language. Reindeer herding has, however, been called into question from several different directions. In this process, which often leads to court, the ability of the Saami villages to present evidence of previous reindeer herding in a region, either in written records or as remains in the landscape, has become an argument for the continued rights of use of certain winter-grazing areas. As a result, archaeology has acquired a new relevance for the Saami villages. But the procedures of archaeological surveys and of the cultural heritage conservation in Sweden are based on ethnocentric assumptions. In a cultural sense, Sápmi of the past and present-day Sweden belong to two different continents, even though they happen to be situated in the same corner of the world. When working with Saami history it is necessary to do away with the distinction between "nature" and "culture", just like a number of other dualisms that are relevant only in a (modern) Western context. If we replace "nature" and "culture" with "environment", we will increase our possibilities to translate Saami history into the language of archaeology and to make archaeology relevant to local people in the mountain region.
\end{abstract}

Britta Wennstedt Edvinger, Arkeologicentrum AB, Storviksvägen 41, SE83433 Brunflo.

Key words: archaeological surveys, ecology, mountain regions, reindeer herding, Saami

\section{TRANSLATING THE PAST}

The Scandinavian mountain region is being marketed by the tourism industry as the last wilderness of Europe. Many people are familiar with this region because of its winter ski resorts and the opportunities for hiking in the summer. For major economic interests the mountain region is a place to exploit natural resources, metal ores, forests and hydropower, while to others the mountain region is simply home. A large number of those who call the mountain region home are Saami, the indigenous people of FennoScandia and NW Russia. This article is about Sápmi, the land of the Saami, and about the practice of archaeology when it takes its starting point in the experiences of local people rather than in the research designs of the universities or the agendas of the cultural heritage conservationists. In the following I will present an overview of an archaeological survey that was conducted in and by four Saami villages in the mountains of southern Sápmi during the summers of 1998-2000. 
I will demonstrate aspects which make the practice of Swedish archaeological surveys problematic when applied in Sápmi, concluding that every Swedish survey in a Saami environment is based on ethnocentric assumptions. If history is a foreign country (Burström 1999), then archaeology is an act of translation. How, then, are archaeologists to understand and represent thoughts and practices of peoples of the past and as far as possible in the terms of the latter? A comparative perspective on the Circumpolar North and the West can help identify areas of cultural divergence. Archaeology is a methodology for the study of non-literate societies and has not exhausted its ability to contribute to this quest. But first archaeologists have to learn about their own cultural standpoints, get rid of some of the most explicitly (modern) Western categories and perhaps extend their understanding of ecology in its widest sense in order to achieve cultural translations that will bear up under scrutiny.

\section{THE SAAMI - FIRST PEOPLE OF FENNO-SCANDIA}

The land of the Saami is situated within the boundaries of four different nation-states, Norway, Sweden, Finland and Russia. The southernmost part of Sápmi of today consists roughly of Nord-Trøndelag, Sør-Trøndelag and Hedmark in Norway and Västerbotten, Jämtland and Dalarna in Sweden. Traditionally this area was characterized by a distinct variety of the Saami language, and it has other specifically south Saami cultural traditions that differ from those of the areas farther north, for example dress code, building techniques, crafts, etc. The total Saami population is 85,000 people, within which the reindeer herders constitute a Saami minority. Out of Sweden's 20,000 Saami only 2,000-4,000 own reindeer, but in spite of the reindeer herders' position as a minority within the Saami community they are important carriers of the Saami cultural heritage (RHIS 1999:9).

The reindeer herders in Sweden are organized into Saami villages. The Saami village is simultaneously a social category and a geographic area, a grazing district. The grazing areas of southern Sápmi are divided into year-round grazing areas on government land and winter-grazing areas on land owned by farmers and forestry corporations. Wintergrazing areas included, about $40 \%$ of the total area of Sweden is used for grazing by 200.000-300.000 reindeer. This need of vast areas for grazing is explained by the characteristics of the reindeer. It feeds on easily digested food during constant wandering, rather than clearing one area of vegetation before moving to the next (Danell 1998:201; RHIS 1999:10). For this reason you cannot fence in reindeer and feed them low-quality fiber-rich hay. The reindeer is domesticated to a very small extent.

In the past the subsistence strategies of the Saami were many and varied according to family tradition, individual life histories, and regional and natural resources. The strong connection to reindeer husbandry of today - so strong that "Saami" is often used as a synonym for "reindeer herder"-- is due to the lesser visibility of other Saami groups. The Saami history of subsistence is complex, and the situation of today with a minority of reindeer herders bears great resemblance to that of the past. We still know very little about the diversity of northern lifestyles of the past (Krupnik 2000:50).

In the twentieth century there was a rapid modernization of the economy of the 
reindeer herders. The reindeer herding economy of today is to a great extent organized according to the requirements of a capitalist market economy. During the period 1600 -1900 , however, reindeer husbandry was conducted in a highly specialized, nomadic manner, which is often called "traditional".

\section{TRADITIONAL REINDEER HUSBANDRY}

Every time you match something "traditional" against something "modern" you wind up with a number of associations that you did not ask for. The traditional appears deemed to forever repeat the same uniform cultural patterns. The modern connotes flexibility, dynamics and change. Traditional vs. modern is one of the many dualisms that Western thinking is constructed around. I use the term "traditional" to describe pre-modern reindeer husbandry, no other connotations intended. It seems that there was a highly specialized variety of reindeer husbandry developing in connection with other changes at the end of the medieval period (in this area ca. 1600), such as a colder climate, a growing population, competition for resources, the extinction of several animal species, a new system of taxation requiring the Saami to pay taxes in livestock, and so forth. Domestic reindeer have, however, a longer history than that. The advantages of reindeer for draught and decoy must have been obvious already to the Palaeolithic wild-reindeer hunters of the Eurasian tundra.

Traditional reindeer husbandry until the early 1900s was characterized by features like milking, intensive watching and transhumance, migrations following a distinct pattern and returning to the same places season after season and year after year. The reindeer were watched night and day during periods when predators were abundant. Virtually every part of the reindeer was made useful in the household: meat and milk for nurture, raw materials for tools, garments, shoes, etc. Some animals were used as draught or pack animals, and the does were used for milking. (Fjellheim 1999:70; Ruong 1971.)

The land-use strategy of traditional reindeer husbandry created a division of the territory and of the year into eight categories or seasons (tab. 1). This division corresponds to certain localities, altitudes and vegetational seasons. Traditionally, the territory was defined by the needs of the sijte - the local band (Bergsland 1995:19) - and those of the reindeer. Later on, administrative boundaries and the presence of competitive activities and economies became crucial to the layout of the territories.

Within the territory there was usually a base area for each season. Certain requirements had to be met: there had to be high-quality pastures; birch-tree forests for constructions and firewood; dry elevated areas for pitching the gåetie, the traditional Saami dwelling; enclosures or other places for rounding up reindeer and milking; dry slopes, defrosted early in the spring for the digging of storage pits; drinking water, preferably spring-water; and if possible, good fishing in the vicinity. (Fjellheim 1999:147.)

In the summer of 1998, four Saami villages in southern Sápmi commenced a survey in 


\begin{tabular}{ll}
\hline South Saami [SSa.] & English \\
\hline Gijre-daelvie-laante & Spring-winterland \\
Gijre-laante & Springland \\
Gijre-giesie-laante & Spring-summerland \\
Giesie-laante & Summerland \\
Tjaktje-giesie-laante & Late summerland \\
Tjaktje-laante & Autumnland \\
Tjaktje-daelvie-laante & Early winterland \\
Daelvie-laante & Winterland \\
\hline
\end{tabular}

Tab. 1. The eight seasons of traditional reindeer husbandry (Fjellheim 1999:69). their own district. The original project design was formulated by Gaaltije - South Saami Cultural Center in Östersund, Sweden. According to this, the objective of the project was to increase the knowledge of the local Saami history by means of a survey conducted by the Saami villages themselves, and thereby to strengthen their Saami identity (Åhrén 1998). The participating Saami villages - Gåebrien sijte and Svahken sijte on the Norwegian side of the border and Ruvhten sijte and Idre Saami village on the Swedish (fig. 1) - appointed one person in each Saami village as coordinator. These positions were filled by Inge Danielsen, Gåebrien sijte, Lars Ivar Danielsen, Svahken sijte and Mikael Andersson, Idre Saami village. Ruvhten sijte was busy with another, similar project and did not appoint a coordinator. The project was financed by the European Union and government funds for cultural heritage conservation. In the last season of fieldwork, two archaeologists participated, Lisa Dunfjeld-Aagård and myself.

The priorities of the Saami villages centered on traditional reindeer herding. Reindeer herders of today are concerned with the history of reindeer herding, a reasonable background for any project of this kind. But there is more to this than meets the eye.

For millennia the mountain region was of no concern to anyone but the local population, but beginning, in Sweden, with King Gustavus I, the Swedish Crown began to lay claims on the territory in the North. Government settlement acts from the end of the $17^{\text {th }}$ century to encourage mining and farming, as well as forestry and the growth of summer tourism at the end of the $19^{\text {th }}$ century, infrastructural developments resulting in roads and railroads, the establishment of national parks, and the building of dams and hydro-power plants in the $20^{\text {th }}$ century are all illustrations to the notion of the North as a commons and as a region to extract resources, which is reminiscent to a large extent of the process of colonization by Westerners in other parts of the world in the same era. For centuries different interests have competed for the land and other resources in the mountain region, often to the disadvantage of local people, who, as a rule, had few opportunities to control events and seldom were consulted concerning plans of development or exploitation. (Kvenangen 1996:49ff; Lundmark 1998.)

When Saami villages today conduct surveys of traditional reindeer herding sites it is not just a pastime during off-season. It is an operation that may be of vital importance for the future of the economy. Winter grazing is the bottleneck of reindeer husbandry, and the access to land which is currently privately owned by the non-Saami is indispensable. The Saami villages have customary rights to keep their herds on private land during winter. Lately there has been an increase in the number of cases where wintergrazing rights have been called into question and brought to court.

There are popular beliefs among the non-Saami in the mountain region that the land was uninhabited when the first Scandinavian settlers arrived. This is the way the 


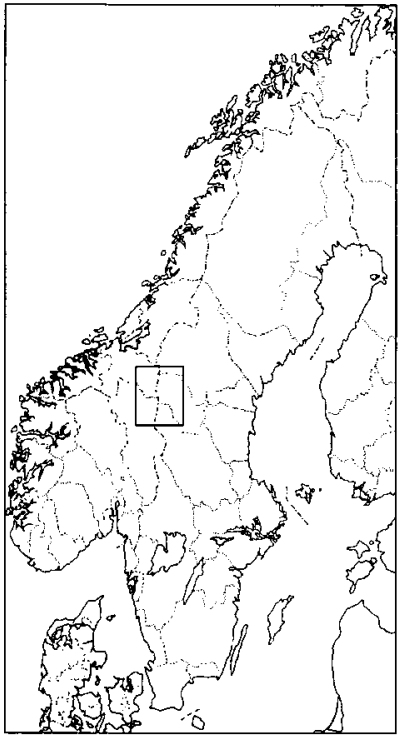

Furthermore, those who wish to keep Scandinavian history Saami-free may lean on research from the $19^{\text {th }}$ century which states that the Saami of the South are recent immigrants (Nielsen 1891). According to this historiography, reindeer-herding Saami moved in to our area of investigation in the $18^{\text {th }}$ century. This line of thought was resurrected and upheld in the $20^{\text {th }}$ century on the basis of historical records and an alleged lack of physical traces of earlier Saami habitation (Haarstad 1992). The same historiography is found within the non-Saami population of that area, probably quite independent of the published research results. The non-Saami may also divulge the name and date of arrival of the first settler. The Saami on the other hand, tell no stories about the first Saami immigrant to this region. There is no such conception in Saami historiography of our area of investigation: "We have always lived here", they claim.

At any rate, the ability of the Saami villages to present evidence of the earlier grazing of an area by tame reindeer may be crucial to its availability for grazing today. But the cultural significance of reindeer herding for Saami society as a whole turns this into not only a problem of feeding reindeer in the winter or a problem of the household income of a number of families, but into a problem of cultural survival (RHIS 1999:9).

Reindeer husbandry is together with forestry and farming considered to be of national interest in Sweden, but in the non-Saami rhetoric it is seldom spoken of as an asset, and its contribution to cultural, social or economical diversity is neglected. In spite of its ranking, it is questioned by a number of different agencies. Scientists claim that trampling and grazing by reindeer is destructive to the mountains (Ihse et al. 1998) and newspapers offer to spread their results (DN 1995). Others claim that reindeer herding is an "obstacle to the tourism industry because of its destruction of sensitive areas by too many reindeer, skidoos and motor cycles' (Fölster et al. 2000), or just plain, unethical cruelty to animals (AB 1997). 
However, destruction must be in the eye of the beholder, since others describe a different scenario: It seems that the presence of reindeer is a prerequisite for the mountain region to keep its qualities. There is a great deal of support for the hypothesis that what reindeer do for the mountains is about the same things as what fires do for forests; in other words that trampling and grazing are necessary for the regeneration of the vegetation and for biological diversity (van den Brink \& Vikman 2000; Oksanen 1998:144f). What is presented as an environmental problem seems to be more of a social problem (Johansson 1998:76ff) or perhaps a cultural problem. The mountains with their reputation as a wilderness must be kept pristine for visitors to conquer, so they can be the first to tread this virgin land. How utterly annoying it is to discover that people live and work here!

"History" and "the past" are separate things. History is a story about the past, told in the present, and designed to be put in the service of the future. History is written or told to fill needs. Thus far, the written history of the Saami, of the mountain region and of the reindeer herders, has not been designed to fill the needs of the Saami, but rather the wants of the tourists, the needs of Scandinavian farmers, the desires of the national romanticists, the purposes of mining developers, the comfort of the authorities and the views of cultural heritage conservationists.

\section{SURVEYING THE SOUTH SCANDES}

Quite a few Saami villages in the southern Saami region have conducted their own ancient monument surveys. These surveys have frequently been the result of local or regional initiatives (Fjellheim 1999; Heinerud 1993; Hemmendorff \& Wennstedt Edvinger 1990; Linnér 1990), while some of them were carried out by the authorities (Hallberg et al. 1974; Linnér 1989a; Linnér 1989b). Since 1996 the National Board of Antiquities has been surveying mountain areas in the three northernmost provinces of Sweden in co-operation with the provincial museums. Earlier surveys on central initiative were carried out by the ethnological Nordic Museum in Stockholm (Kjellström 1983; Manker 1945), in accordance with the Western notion that non-literate peoples lack history but have ethnography.

Norway and Sweden have a long border in common, but in regard to Saami issues the two nation-states often choose different strategies. Norway has, for example, ratified the United Nations ILO (International Labour Organization) Convention \#169 on Indigenous Peoples. Sweden has so far declined to do so (SOU 1999:25). Another difference concerns the cultural heritage conservation. The Saami administration in Norway (Sametinget) has established a department of environmental and cultural heritage conservation. The establishment of a Saami cultural conservation institution was not a process entirely without disagreements. These disagreements appear to have their background in Saami - Norwegian cultural differences (Fjellheim 1991). In Sweden, matters of cultural heritage conservation are dealt with by the administrations of each province. There is no Saami institution with formalized influence over how the Saami cultural heritage is dealt with in Swedish management. 


\section{TRACES ON A MOUNTAINSIDE}

In the following I will give a brief description of the environment of the traditional reindeer herders, as we found it on the mountainsides and in the valleys of the reindeer herding districts near Idre, Gåebrie and Svahke. This is not a comprehensive summary of features of the south Saami reindeer herders' historical landscape in the area, but merely a brief presentation of the material we recorded during the last season of fieldwork (tab. 2). The areas surveyed are situated $550-1,000$ m.a.s.l. Most of the surveys were done just below the timber-line, that is, at altitudes varying between 700 and 900 m.a.s.1.

Two different administrative organizations supplied methodologies. The Swedish ancient monuments survey of the National Board of Antiquities supplied standards for description. The Saami cultural conservation in Norway supplied a strategy for selection of phenomena to record. We considered the Saami cultural conservation procedure more relevant for two reasons. It was developed in a Saami cultural context, and it takes its starting point in broad, inclusive functional categories ("dwelling", "storage", "hunting and trapping", "fishing", "reindeer round-up site", "migration route" etc.; cf. Fjellheim 1999) instead of in exclusive objects (cf. Fälthandbok 1997). The former encourages a relational perspective; when each recovered trace is seen as an aspect of a totality, this certainly can inspire the surveyor to, as it were, recover the missing parts in ways that apparently discrete objects cannot.

In the presentation below I aim to draw attention to the choices of perishable raw materials for construction, to the few examples of transformation of the ground, and to the vegetational evidence of land use.

\section{Pastures}

The "wilderness" of the mountain region bears a strong imprint of grazing. Biologists call this environment semi-natural. Semi-natural plant communities consist of species that are dependent on people for their long-term survival. The mountain region bears witness to grazing by domestic animals, which makes it a semi-natural landscape (Liavik 1999; Olsson 1996). Pollen analyses have demonstrated that periods of intensive grazing by animals alternate with less intensive periods throughout history (Wallin \& Aronsson 1998). The appearance of the mountain region today is in other words the result of present and previous land use.

\section{Giedtie-aevjieh}

The extensive reindeer herding of today is obviously mirrored in the vegetation of the mountains, but the intensive, traditional reindeer herding also left its mark in the vegetation as well as physically, as the remains of constructions. Characteristic features are the giedtie-aevjieh, former enclosures where reindeer were rounded up and kept for milking during the lactation period in the summer and early fall. A giedtie is a fenced enclosure, built with the Saami standard units of construction, namely forked poles, rods and birch twigs. Forked poles or rods were raised against each other as trestles with rods between, and twigs were placed vertically, resting on the horizontal poles. 


\begin{tabular}{|c|c|c|c|c|c|}
\hline Eng. & $S S a / S w$ & Idre Saami village & Svahken sijte & Gåebrien sijte & $\sum$ \\
\hline enclosure & giedtie(-aevjie) & 27 & 3 & 5 & 35 \\
\hline dwelling, gåetie type & gåetie(-sijjie) & 3 & 4 & 17 & 24 \\
\hline cairn & stensamling & 17 & 0 & 3 & 20 \\
\hline storage pit & boerne & 2 & 4 & 3 & 9 \\
\hline hunting pit & vijreme-svaalke & 7 & 2 & 0 & 9 \\
\hline prospecting pit (ore) & prospekteringsgrop & 3 & 0 & 5 & 8 \\
\hline dwelling, other & kojtomt/-rest & 3 & 3 & 1 & 7 \\
\hline turf-collecting site & torvtäkt & 2 & 1 & 4 & 7 \\
\hline spring & gaaltije & 5 & 1 & 0 & 6 \\
\hline grave & gaelmie & 0 & 3 & 2 & 5 \\
\hline hearth & aernie & 1 & 3 & 0 & 4 \\
\hline sacrificial site & sjiele-sijjie & 0 & 0 & 4 & 4 \\
\hline storage house & buvrie(-sijjie) & 0 & 0 & 3 & 3 \\
\hline charcoal stack & kolbotten & 0 & 2 & 0 & 2 \\
\hline tarring pit & dervie-maejla & 0 & 0 & 2 & 2 \\
\hline quarry & kvartsbrott & 0 & 0 & 1 & 1 \\
\hline dwelling, lihpie type & lihpie & 0 & 0 & 1 & 1 \\
\hline archer's hideout & skåre & 0 & 0 & 1 & l \\
\hline house foundation & ståapoe-sijjjie & 0 & 0 & 1 & 1 \\
\hline \multirow[t]{2}{*}{ sedge-collecting site } & suejnie-tjuahpa & 0 & 1 & 0 & 1 \\
\hline & & 70 & 27 & 53 & 150 \\
\hline
\end{tabular}

Tab. 2. Results of the $1998-2000$ south Saami village survey of historical reindeer herders' sites.

The milking of reindeer in our area of investigation ended in the early $20^{\text {th }}$ century (Falkenberg 1985:8ff). There are seldom any remains of the fences preserved, but there are signs in the vegetation caused by natural conditions and circumstances when the enclosure was deserted. Today these giedtie-aevjieh appear as round areas, 20-40 meters in diameter, covered with both grass (Nardus stricta) and juniper (Juniperus communis) or a number of different herbs and juniper, depending on the local natural conditions. Much of the time they are visible only thanks to a dense birch-tree grove in the abovementioned circular shape. On closer scrutiny of the giedtie-aevjieh, where the enclosure lay on a slope, you may also find physical traces at the place of the fence at the lower end where soil erosion has formed a terrace.

A vast majority of the deserted enclosures in the valleys, well-manured and cleared, have been turned into farmsteads or haymaking areas by settlers, Saami and non-Saami.

\section{Gaaltijeh}

Gaaltijeh, springs, were important features of the environment of traditional reindeer herding. There is always water to be found adjacent to giedtie-aevjieh and dwelling sites. Water was essential for drinking, of course, but also for the cold storage it provided. Sometimes you can identify the remains of constructions, or the clearing away of rocks or digging at gaaltijeh, but just as often there are no signs of the like. A characteristic construction is a small dam that provided plenty of room for milk kegs (Wennstedt Edvinger \& Winka 2001:35f). 


\section{Gathering}

Wood is preserved for long periods of time thanks to the arid climate in the south Scandes. Old stumps deteriorate very slowly, and for centuries you may discern traces of woodcutting at the dwelling sites. Very often the stumps are of pine in areas that have no coniferous forest today but only the characteristic birch trees, a reminder of those times when the climate was growing colder and the timber-line retreating.

Birch-bark was used for several different purposes; the largest quantities formed the wall-covering of the gåetie. Another type of bark that was widely used but for different purposes was the inner bark of the pine tree. Dried and roasted pine tree bark was a part of the diet. The Saami collected the pine-bark in a manner that did not kill the tree, namely by cutting a rhombic section (Korhonen 2000; Niklasson 1996). These characteristic traces are still found on older trees in some areas. Most of our surveys took place above the coniferous timber-line and we were not able to recover any pine trees with rhombic cutmarks.

Turf was an important building material for the traditional dervhvie-gaetie, which will be described in the following section. Today you can find sites where turf or peat was collected, in the shape of square marks on grassland or in mires. The size of these marks varies. To turf a gåetie according to south Saami tradition you would need around $10 \mathrm{~m}^{2}$. There must have been a turf-collecting site close to every derhviegåetie, but very few are recorded.

Yet another type of reaping is the gathering of sedge for shoe-lining. Different Carex-species - preferably Carex vesicaria and Carex rostrata - were cut, combed and dried and then twined into rings and kept until needed (Axmann 1992:249; Drake 1918:182f). Oral tradition is at current our only means of recovering sedge-gathering sites.

\section{Dwellings}

The gåetie, the traditional Saami dwelling, appears in a variety of shapes. The framework was either of the bow-shaped type, otneresh-gåetie (fig. 2), or of the forked type, tseagkere-gàetie. The wall-covering was either of the afore-mentioned turf (derhviegåetie) (fig. 2), of homespun or, more recently, of canvas (låavth-gåetie). Wood, birchbark and turf were used for construction, and occasionally a few rocks were placed at the base of the gåetie. The local tradition, season, planned period of use, function, need of mobility, and natural conditions are some of the factors that affected the choice of gåetie type.

In the south Saami area it was common to cover the gåetie with sheets of turf. These were kept in place by vertical birch-tree rods. When a derhvie-gaietie deteriorates it turns into a circular turf wall, $5-8$ meters in diameter, with an aernie, a rock-lined hearth, in its center. The remains of a låavth-gåetie are much more insignificant - a flat, circular stone-cleared surface with an aernie in its center. Sometimes there is an outer row of rocks that was used to keep the canvas straight. Aernieh are also sometimes found without a surrounding gåetie-sijjie.

Another type of gåetie that turns into a distinct type as it deteriorates is the kåavagåetie (fig. 3), a gåetie with an entrance hall. Households that needed extra space 


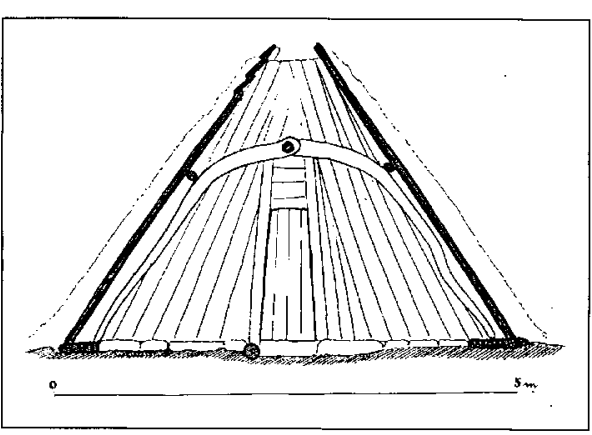

Fig. 2. South Saami derhvie-găetie of otneresh type (NM 1943). would build a kåava onto their gåetie. Some were of timber and some of rods, birch-bark and turf.

Other remains of dwellings associated with a historical reindeer-herding site are the foundation of a stone house, a log cabin, or a cabin with stone oven (Fjellheim 1999: 262ff; Sveen 1989; Wennstedt Edvinger \& Winka 2001:73). Quite frequently, goats were kept at the summer sites. They were stabled in a tjiejhte-gåetie or a square open shed of rods, birch-bark and turf.

One type of dwelling with few if any descriptions in the literature is the lihpie. A lihpie is a rock or a rock shelter. At the lihpie we recorded, there was a stone wall and a dry stone oven next to and beneath a rock (fig. 4) (Wennstedt Edvinger \& Winka 2001:109). In the summer of 2001 another lihpie was recovered in the same district, Gåebrien sijte (Inge Danielsen, pers. comm.).

\section{Storage}

At the dwelling site there were storage spaces of various kinds. A vast majority of the storage spaces discernible today are pits. The reason for this is not necessarily one of tradition, however. Many of the storage spaces used leave no marks in the landscape. Balkoe, a tripod of birch rods, is an illuminating example. Another example is a log storehouse built on one, four or more high stumps of coniferous trees (fig. 5). In treeless environments you may sometimes come across stone-lined postholes, and the environment will normally disclose their functional background as belonging to either giedtie or balkoe. The most commonly used temporary storage space was probably the nearest birch tree or spruce (fig. 3).

Boernh are characteristic of these sites. This category covers storage pits of all sizes and depths. A classic boerne for milk storage is a rectangular pit at the top or on the southern slope of a moraineformation, or any well-drained place with a minimum of frost that would thaw rapidly in the spring. The pit itself would be the size of the milk keg that was kept in it, ractangular and less than $1 \mathrm{~m}$ long.

Fig. 3. Per Rikard Jonsson in front of a kåavagåetie near Töfsingsjön, Slugufjäll, Dalarna. Photo by Karl-Erik Forsshund, 1916 (Museum of Dalarna, Falun, acc. 215:14).

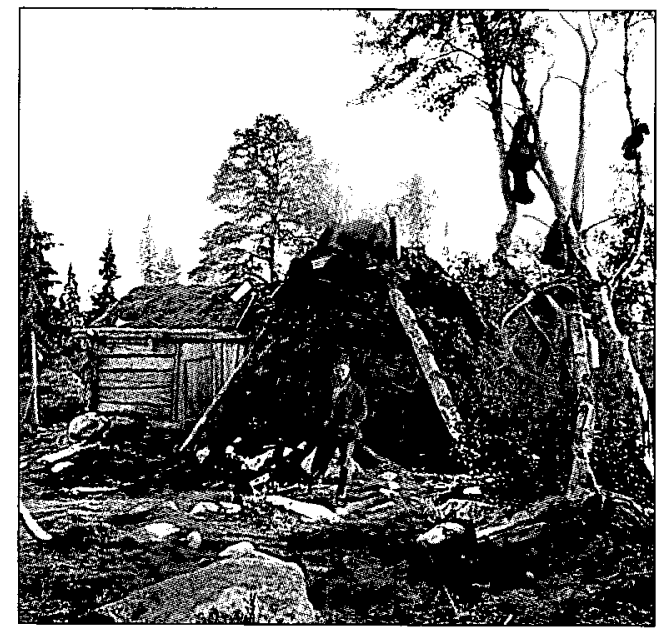




\section{Bone rooms}

Every dwelling site had to have a bone room where one collected the bones of reindeer and game after every meal. Fish bones were excluded. (Sjulsson 1979:126.) Each bone had to be taken care of and deposited according to certain rules. Bone rooms at the summer sites were located either in stone formations or in a constructed cairn, in a spring, creek or lake, or on top of an erratic block (Drake 1918:58; Sjulsson 1979:

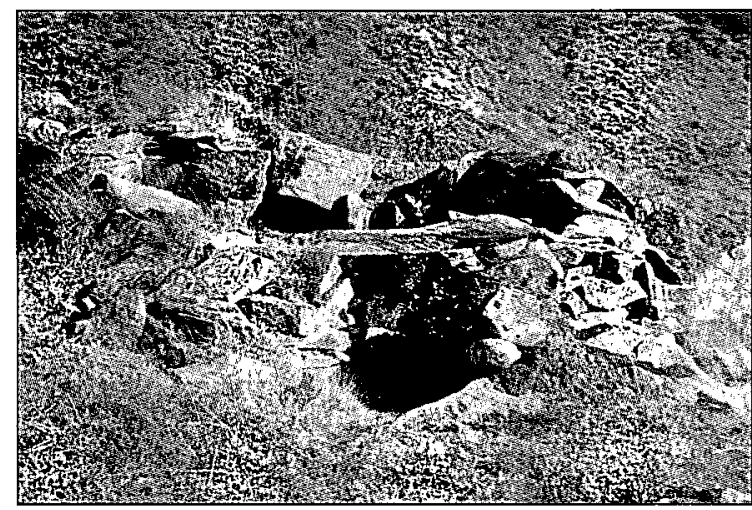

Fig. 4. Malenagrotta, a lihpie with a stone oven near Holdsjøen, Holtålen, Sør-Trøndelag, Norway. Photo by Inge Danielsen, 2000. 127). In the winter the bones were placed on a platform on a high stump well above the ground (Sjulsson 1979:127).

Bordering bone room and human grave is the bear grave, a burial-ground for the bear skeleton after the ritual meal that followed every successful bear hunt (Zachrisson \& Iregren 1974; Wennstedt Edvinger 2000). Such bear ceremonies were held all over the Circumpolar North before modernization, but the Saami alone buried the bear at the end of the ceremony. Rules for deposition of the animal bones are expressions of Saami human-animal relationships, and the Saami tradition in this respect as well as many others is a parallel to those of the other Circumpolar peoples (cf. Brightman 1993; Cruikshank 1998; Ingold 2000; Tanner 1979; Wenzel 1991).

We have recorded a number of small cairns which do not mark paths, and we expect a few of them to be bone rooms of one sort or the other. Small cairns are also reported to have been built in connection with Saami animal scrifice (Qvigstad 1926:354f).

\section{Hunting and trapping}

The reindeer herders of the period under discussion probably did not have much time to hunt for game, since watching the reindeer kept the household members busy on a 24-hour basis during at least part of the year. The hunting of predators, on the other hand, in particular wolves, was necessary to protect the reindeer but also provided a cash income thanks to bounties from Government funds. Trapping of small game and birds was a standard subsistence activity. Trapping and hunting techniques in Sápmi are described in a number of publications (Ekman 1910; Henriksson 1978; Kjellström 1995). The most commonly used methods for bird and small game trapping, such as snaring, or for hunting predators, such as spear, bow and arrow and, later on, firearms, did not leave any traces in the landscape.

In contrast, vijreme-svaalkeh, hunting pits for wild reindeer and elk, represent the most extensive groundwork that ever took place in a pre-modern Saami context in the mountain region. The hunting pits are legio, and the Saami use of them is well recorded (Drake 1918; Sjulsson 1979). But reindeer herding is difficult to maintain in an area 


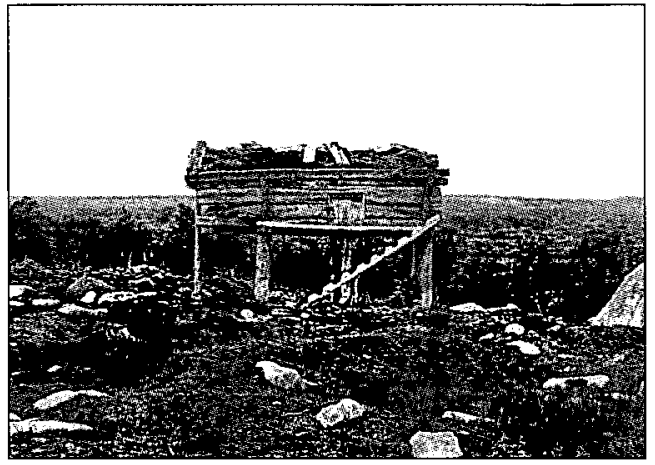

Fig. 5. A storage house at Hävlingskällorna, Idre parish, Dalarna, and in the foreground, a derhvie-gåetie-sijjie in the shape of a circular wall. Photo by Karl-Erik Forsslund, 1912 (Museum of Dalarna, acc. 215:17).

with wild reindeer (Lars Ivar Danielsen, pers. comm.; Kvenangen 1996:41). The tame reindeer will inevitably wander off with their wild counterparts if the latter form a majority. The extinction in Sweden of wild reindeer in the $17^{\text {th }}-19^{\text {th }}$ centuries has been put in connection with the increase in reindeer pastoralism during the same period. A small number of wild reindeer would soon have been rounded up with the tame reindeer and either slaughtered or ear-marked, making them tame reindeer by definition (Oksanen 1998:143f). In southern Norway there is a government-managed wild-reindeer population, but these animals are kept well away from the reindeer herding districts (Jordhøy 2001).

\section{Sacred places}

The Saami religion was shamanistic, and animal sacrifices were an important component. Sjiele-sijjich, sacrificial sites, have been recorded in all parts of the mountain region. The classic Saami sacrificial site is found at a protruding element in the landscape, at a rock, an erratic block, or on a point. There are seldom any constructions, but animal bones are frequently found at the sites. Most of the earlier recorded sacrificial sites are or were known by local people, and the surveyor did not have to rely on mere physical traits for identification (e.g., Manker 1957). The lack of constructions or bones does not make an area less sacred, only more difficult to register as a sjielesijjie. Sjiele-sijjieh that are not known in local tradition will only be recorded if there are constructions like sacrificial altars, which sometimes occur. At the sjiele-sijjieh you can also sometimes find plants that are not in their natural habitat, e.g. Angelica archangelica (Sw. "kvanne", "björnstut") on a high mountainside.

A different type of sjiele-sijjie, which is actually man-made, is the circular-shaped sacrificial site (fig. 6). Such sites are known throughout Sápmi (Wennstedt Edvinger \& Winka 2001:39ff).

Other cultural features, for example the stone seite tradition of northern FennoScandia or the sacred mountain concept, were not practiced and not recorded respectively, in our area of investigation (cf. Qvigstad 1926:354f).

\section{Gaelmieh}

The burial customs of the Sami varied a great deal, and whether the dead were buried in the ground or not depended first and foremost on the season of death (Manker 1961; Schanche 2000). All of the gaelmieh (graves) in our area of investigation are located in the same type of environment, namely on a ledge on a mountainside with a 
wide view, but the morphology differs and ranges from stone-settings to unmarked graves below ground (Wennstedt Edvinger \& Winka 2001:41f).

Most of the gaelmieh recorded in the mountain region are older than 300 years. The national registration and the Church's control of the population at large were increased in the $18^{\text {th }}$ century. Burying the dead according to Saami tradition was an offence in the view of the central administration and the Church. This is the background of the Saami summer graves in the high mountain areas, burial-grounds where the dead were kept temporarily until they were unearthed and brought to the church and churchyard at the time of moving to the lower land in the late fall.

\section{Dervie-maejla}

Adjacent to dwelling sites you may also find a dervie-maejla, a tarring pit. Tar was boiled for household use or for sale. Sites with a gåetie and a tarring pit occur in several parts of southern Sápmi (Fjellheim 1999:309ff; Manker 1945:184; Wennstedt Edvinger \& Winka 2001:45).

\section{Boundary marks}

The tax land mode of organization meant that each south Saami sijte had its own territory, with carefully defined boundaries, which could be sold or inherited. Boundarymarkers either built of rocks or as marks on trees were in use until the Reindeer Pasture Law of 1928 broke up the older tax land organization and substituted reindeer breedingrights, setting the majority of the Saami people, the non-reindeer herders, apart (Kvenangen 1996:82ff; Lundmark 1998:105ff; Ruong 1967:89; Päiviö 2000).

\section{Paths}

Finally, communications in traditional reindeer-herding areas consist to a large extent of the migration routes. These routes are, as it were, in the land rather than on it, and they are not marked in any way. Paths, on the other hand, may be marked out when leading through rough terrain. Paths through extreme boulder moraine like that of the South Rogen area in Härjedalen may be marked by placing one stone on top of another at certain intervals (Jonas Danielsen, pers. comm.).

There are great numbers of small cairns built by tourists or marking tourist trails. These are normally easily recognizable as such because of their mode of construction, size, age and location.

In what ways did our survey differ from other

Fig. 6. An example of a circular-shaped sjiele-sijjie that reflects parts of the ritual sequence: the offering of an animal (a stone circle), the preparation of the ritual meal (a hearth), and the bone room (a small cairn) (Wennstedt 1989:30).

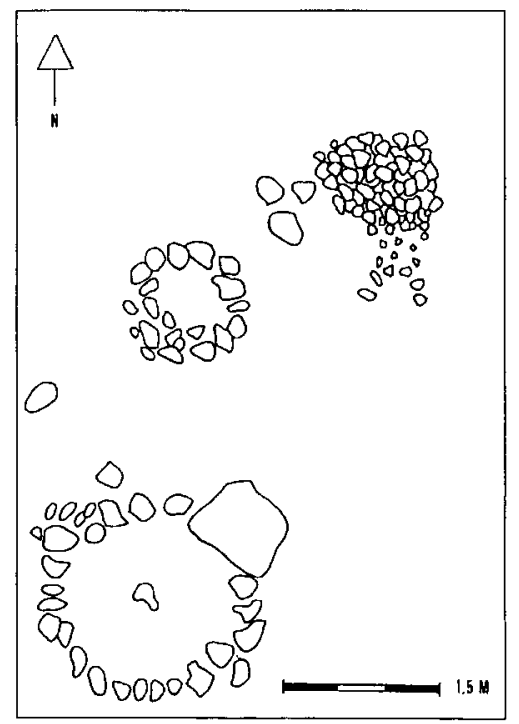


archaeological surveys of the mountain region? There are a number of differences but I will only comment three of them. The first concerns the crew. Our crew was made up of a minority of professional archaeologists. The recruitment of local people brought to the project an unsurpassed knowledge of the area in question, and a focus on the understanding of local living conditions. Furthermore, a number of participants were quite experienced in the field of surveying after conducting several similar surveys in previous years. In this context of experienced people with great knowledge of the landscape, which, if any, were the archaeologists' contributions? In short, we brought comparative data on other regions in the mountains and elsewhere, routines of registry, knowledge of climate history and its effect on living conditions, and methods of remote sensing.

The second difference I wish to mention here is our focus on vegetational evidence of previous land use. This attention to the vegetation resulted in a large number of recorded giedtie-aevjieh. As a consequence, the general attention to vegetational data increased, which in its turn provided additional clues to the locations of further sites: varieties of grass, flowers, stumps of coniferous trees, etc.

The third difference is closely tied to the second and concerns the scope of the survey. In one sense our scope was narrow, narrower than the ongoing government financed archaeological surveys of the Swedish mountain range; we concentrated on traces of traditional reindeer herding solely. But in another sense we transcended the limits of conventional archaeological surveys by widening the selection of recordable traits, incorporating for example vegetational evidence of giedtie-aevjieh and turfcollecting sites or the gaaltijeh, springs. Neither of these would attract the attention of a conventional archaeological survey, but they were of course crucial to their users. We will turn to this difference of perspectives in the following section.

\section{DIFFERENT CULTURES}

Throughout the Circumpolar North local people forcefully protest against their homelands being called a "frontier" or a "wilderness" (Nuttall 1998:87; Åhrén 2001:iii). The Scandes have been inhabited since the end of the last glaciation 8,000 to 10,000 years ago, utilized more intensively in periods of favorable climate and on a shorter seasonal basis in colder periods. Various activities have left different kinds of traces; many have left no mark whatsoever. To view this region as a wilderness requires a certain perspective. The mountain region can only be a wilderness to a stranger; for the local people, it is saturated with memories and meanings. This situation points to one of the greatest problems with filtering the Saami cultural heritage through the categories of the Swedish cultural heritage conservation. It is not a matter of mere technicalities in the practice of surveying; it is a matter of ontology.

The beginnings of Saami research, the "Lappology" of the late $19^{\text {th }}$ century, were heavily burdened by social or cultural Darwinism. More recent research has, at least in theory, cast off the shackles of cultural evolutionism and racism, but a patronizing popular view of the Saami as a recent and exotic peculiar little people in the far North still prevails. From a (politically) central Swedish point of view, northern Fenno-Scandia 
may appear as a dead end and the Saami as greatly dependent on their neighbours in the South, and this was certainly the case for the Lappologists. In line with this reasoning, the Saami were regarded as passive receivers of cultural traits and influences from the South. But the far North was not the end of the world, and the dead-end conception was of course entirely erroneous. Saami culture, past and present, is proof of that.

It was a step forward for Saami research in Scandinavia when scholars detected connections between Saami culture and cultures of Siberia. In Sweden, studies in the history of religion brought this connection to attention. It was obvious that features of Saami religion could no longer be explained solely in terms of cultural traits borrowed from the Scandinavians, but rather in terms of similarities with a vast geographical area in the East. Today, with a growing body of knowledge on the anthropology of the North, it is clear that traditional Saami culture is better understood as related to the (former) hunters and gatherers of the Circumpolar North; the Khants, Sakhas, Nivkhi, Evenks, Evens, Chukchi, Inughuit, Kalaallit, Athabascans, Aluttiq, Yup'ik and Inupiat. In a cultural sense this area forms a continent of its own.

The Circumpolar North, roughly the region north of $60^{\circ} \mathrm{N}$, today has a population of about 10 million people, of which 1.5 million are indigenous (Nuttall 1998:2ff). The indigenous population is small and - with the exception of Nunavut - conformed to nation-states in the South, whose, in this context, recent boundaries have reduced these indigenous peoples to minorities. Among these minorities, the shamanistic belt of the North, you can search and find those features that motivate ascribing them a common cultural background: similar mythologies, animist religions, cosmologies, rituals, human-animal relationships and so forth.

There is an important distinction between the Saami and other Circumpolar peoples. In Sápmi there was no pre-contact situation of the type known from other areas colonized by Westerners in the last five centuries. For as far back as we can trace them, the Saami have interacted with people of different cultures, languages and beliefs.

We still know very little about this interaction, mainly because of the lack of research. Above I mentioned some of the limitations of earlier research, where the theoretical framework of cultural evolutionism impaired research progress. Another difficulty concerns the sources. There is only a certain amount of historical records available, and very often they were produced under circumstances that make them difficult to use. The Saami religion is an excellent example.

A vast majority of the sources on Saami religion were written down in the $18^{\text {th }}$ century by one and the same person, Thomas von Westen. To collect this information he had to rely on interpreters, since he spoke and understood very little Saami. Unfortunately, the interpreters' linguistic abilities were often just as deficient. His informants were either paid or threatened to perform this service. Only one social category was engaged, reindeer-owning men. von Westen targeted the Saami shamen, and all interviews took place within the same Norwegian, south Saami region. In spite of all this, von Westen's material, which was collected for the purpose of obliterating the Saami religion, has been taken as a full description of the Saami religion, common to all Saami before Christianity. Recent research points to a different picture. (Hultkrantz 
1985:23; Lindkjølen 1994; Mebius 1968:163; Myrhaug 1997:110f; Rydving 1993:152; Rydving 1995:28f for details.)

The history written thus far is to a great extent the history of the strangers to the region; the historical Saami records were produced by the non-Saami representatives of the central administration and, further, very often the records were worked on by non-Saami scholars. Professor Knut Bergsland is reported to have characterized Saami research some 20 years ago as research done by non-Saami for non-Saami (Torp 2001). Non-Saami scholars decided which of the Saami cultural traits were valid research objects and problems, and very often they chose traits that were either recognized as Scandinavian or that made sense from a Scandinavian cultural standpoint, such as loan-words, deities, material culture, etc. They were unable or unwilling to penetrate other phenomena that were strange to them but significant from a Saami point of view.

We have rejected the perspectives of Lappology. Consider for a moment, figuratively, also throwing out the central administration of Sweden as a nation-state. Instead of civilized vs. savages, as in the $19^{\text {th }}$ century, or nation-state vs. minority, as today, we are dealing with two different cultural continents.

\section{Nature : culture}

Thanks to recent anthropological developments, there is much improvement in our possibilities to understand the differences between on the one hand the Western thinking that directs science and management and, on the other hand, the perspectives on the environment and local production of knowledge in the Circumpolar North (e.g., Anderson 2000; Ingold 2000; Nuttall 1998). With regard to archaeological surveys of the environments of reindeer herding communities of the past, there are aspects of special interest that require further exploration, namely ecology and differences in relation to the environment.

As a Westerner you learn that history is created through the process of taming, improving and refining nature (cf. Childe 1942:55). You have to rise above nature to become truly human. This perspective requires a strict division between the world of nature and the world of society or culture, and it is so fundamental to Western thinking that it constitutes one of its definitions. In other parts of the world, however, people do not make this distinction between the world of nature and the world of society (Ingold 2000:15ff).

Ocularcentrism, the ranking of vision above all other senses, is another Western peculiarity (Clifford 1998; Ingold 2000:245ff). This hegemony of vision in conjunction with the Western nature/culture dualism has, of course, implications for the practice of archaeological surveys. This determines how we classify remains into hierarchies of recordability, crowning the most valuable ones in the National Ancient Monuments Record, the true ancient monuments, with a runic $\mathrm{R}$, and ascribing to others a lower status as mere entries ("numbers") in the same exclusive archive.

In the history of the archaeological surveys by the National Board of Antiquities, new strategies have replaced the old, but the constructed and the visible have never lost their status. The main criteria for registration are visibility, visible boundaries and 
transformation. "Is it natural or is it man-made?" "If you haven't transformed Nature you haven't built Culture and Civilization".

Consider a different ontological situation, where nature is not an enemy but more like a parent who supplies protection, guidance and nurture, and where all elements of the environment are animate. Where a person is a position in a field of relations and where personhood is a category open to humans and non-humans alike. Where there is no concept of nature opposed to culture, and hence no concept of the supernatural. Where there are no culturally defined goals that force you to transform and improve nature, and consequently there is no need for people to distance themselves from their environment to become truly human, to manifest their control and dominance. Where the ground you tread upon is inhabited by others, who walk with their soles against your soles. (cf. Fellman 1910; Qvigstad 1903; Reuterskiöld 1910; Wiklund 1897-1905.)

\section{Knowing the land}

For a long time scholars dismissed local or traditional knowledge as inaccurate and lacking scientific legitimacy. Recently, however, there has been an increase in the interest in local or traditional knowledge in general and in ecological knowledge in particular.

Local ecological knowledge and scientific knowledge differ dramatically. The Western scientific ideal favors a production of knowledge that is context free, impersonal and propositional, formalized into theories and designs. Local knowledge is practical rather than theoretical. It is "knowing how" rather than "knowing that" and a way of attending to the world. It does not exist as formalized theories; it is contextual and situational, it is tied to and takes its meaning from a place and a situation. It is personal and generated and regenerated through fields of practice. (Anderson 2000:116ff; Ingold 2000:24ff; Nuttall 1998:71ff.)

In the historical record there are very few accounts of Saami perceptions of the environment, but as a field of research this arena is growing. There are also a few firsthand accounts from present-day reindeer herding. I do not believe that the reindeer herders of today have preserved pristine relationships to the land - first and foremost because relationships are personal - but the point is that reindeer herders know the land. Certainly, there are differences in the way people relate to an environment. Claims have been made that Saami relations differ from those of the non-Saami, and that the relations of Saami reindeer herders differ from those of Saami hunters and fishermen. These relations have been described as "a Saami room" (Åhrén 1988:117ff).

Concepts that are central to this notion do not have definitions applicable outside the Saami room. They designate patterns and laws that govern the movement of reindeer herders through the landscape. They seldom lend themselves to formalization, although sometimes they take the shape of simple formal rules, for example, "Move in a certain way in relation to how the wind blows". More often, however, they contain a complex interplay of different elements. In the Saami room there is a close relationship among reindeer, people and the land (Åhrén 1988:122).

The article cited above was written in an attempt to translate aspects of a Saami reindeer herder's perception of the environment into the language of the non-Saami. In 
the language of anthropology, one might say that the reindeer herders relate to the environment in a multi-sensory and relational manner. Their knowledge of the environment is thus a sentient ecology (Anderson 2000:116ff) that is based in feeling, that is, on the skills, sensitivities and orientations that have developed through long experience of conducting one's life in a particular environment.

\section{CONCLUSION}

I have tried to address the problem involved when archaeological surveys in Sweden and other multi-cultural nation-states filter the cultural heritage of one people through the cultural constructions of another. This is an activity that archaeologists participate in a great deal of the time, but it is seldom so obvious as when working in an indigenous context, or for that matter probably in any co-operative project on a local basis.

To date, Swedish archaeological surveys have focused on features of Saami history that overlap the categories of the Swedish majority. When an archaeological survey in Sápmi concentrates on the physical traits that distinguish the natural from the cultural, it is done without reflection over the cultural practices of the local population. In popular non-Saami rhetoric, the lack of evidence for Saami transformations of nature is recorded as evidence of a given region's non-Saami history, as a means of making Sweden Swedish: The Saami are recent immigrants, it is claimed, but what it all comes down to is a case of ethnocentrism taken to court. It is obvious that you cannot tell whether or not an area has a Saami history simply by judging the extent to which people left traces in the landscape that concur with categories relevant to the nonSaami. It is equally absurd when the courts of law enjoin the Saami villages to present written records (of a historically non-literate people) or transformations of the landscape (by a people with no cultural goals of transforming nature) as evidence of the previous use of an area for reindeer herding.

The mountain region is frequently referred to as a "wilderness", but wherever you go there are traces left by earlier users. In 1950 Ernst Manker described the Swedish mountains as a cultural landscape, referring to the great number of ancient dwellings he was shown or otherwise came across during his fieldwork (Manker 1950). But the traces of earlier use are not confined to the ancient monuments. They also consist of the stretch of the timber-line, the presence or composition of fish populations in the lakes, the flowery meadows and many other phenomena that all have in common that they very often are human-induced. There is no virgin territory, no wilderness, no "natural" nature of the mountain region. In a rather similar manner, the cultural-historical elements of the mountain region did not gain their significance as a result of alterations and transformations. A phenomenon may have (had) a tremendous significance without a single alteration ever being made, as for example Saami sacrificial sites or sacred mountains.

The mountains are simultaneously "nature" and "culture"; they are not exclusively one or the other. For that reason, and regardless whether you consider the operational side of surveying or the cultural history of the region, archaeologists working in the mountain area will find it impossible to maintain the distinction between nature and 
culture. The operational difficulties consist mainly in an inability to recognize the traces of earlier use because they are identified as "natural", the deserted enclosures giedtie-aevjieh - being a good example. The cultural-historical aspect involves what I addressed above as the archaeologist's understanding and representation of thoughts and practices of peoples of the past. I cannot give an exhaustive answer to the question raised, but only point in a certain direction, a direction that once again touches upon "nature".

"Environment" is about "nature", and as such we, as humans and adherents to a specific philosophical tradition, are not a part of it. We don't belong to the world of nature, but to the world of culture. Environmental thinking, as in "nature", however, is not strange to archaeologists, and it has for example been suggested that nature conservation and cultural heritage conservation should join forces (Gren 2000). With regard to Saami history, if we cannot apply the standard procedures of recording physical traits, then we have to develop other techniques. Working with flora and fauna is a feasible strategy, as discussed earlier, but an environmental approach may have further implications. It may have bearing on how we approach the problem of understanding and representing the thoughts and practices of peoples of the past.

The Swedish word for environment (miljö) is a French loan-word meaning "at the center". To be au milieu is to be surrounded on all sides. The milieu or environment in this sense is relative. We cannot move ourselves out of it, nor can we look at it from afar as we do with for example environments transformed into maps. The environment is constantly coming into being around us; in this sense it is not a unit but a process. A concept of environment where there is no distinction between "the cultural" and "the natural" is reminiscent of the sense of relatedness described by Ingwar Åhrén as "a Saami room" and by David Anderson as "a sentient ecology".

Above I have claimed that archaeology can contribute to Saami history of the last millennium in ways that historians cannot. Too many processes and events are invisible in the written record. So who but the archaeologist can fill the gaps of the historical records and challenge the views they express? If this would be the archaeologists' contribution to Saami history in general and the history of reindeer herding in particular, what, then, would the Saami contribution to archaeology be? A great oversight of Scandinavian archaeology is to ignore the insights into traditional life-styles that Saami historical ethnography has to offer. It contains comments on the conditions of traditional life in a boreal area. As such, it is highly relevant to many archaeologists. On a local level and in the light of the section above on "nature", a different contribution is the reindeer herders' insights into the local ecology. But not ecology as in "nature", but as in "knowing the land", as a sense of active engagement, "a close relationship among reindeer, people and the land".

Archaeologists working in the mountain region are privileged. We work under natural conditions that have changed very little through the millennia in an area inhabited by people whose local knowledge made living here possible. Through their willingness to share their experiences with us, and our willingness to listen, we can gain a totally different understanding of the living conditions here in both the past and the present 
and of what traces the people of the past left in the landscape. This kind of knowledge cannot be acquired by remote sensing or extraction from a map; it is not found in the university library or on the shelves of the bookstore. But it might be acquired by positioning oneself in a field of relations, that is, an environment.

\section{EPILOGUE}

On February 15, 2002, Idre Saami village, Ruvhten sijte and three other Saami villages were sentenced by the Swedish court of appeal to forfeit their customary rights to winter grazing on privately owned land. The verdict was based on lack of evidence of previous Saami land use and grazing by tame reindeer on the properties in question.

\section{English revised by Laura Wrang.}

\section{REFERENCES}

AB 1997. Aftonbladet Sep. 30, 1997. Debate article by Johansson, K.-O., Lindberg, Ch. \& Westerlund, S. Anderson, D. 2000. Identity and Ecology in Arctic Siberia: the Number One Reindeer Brigade. Oxford. Aronsson, K.-A. 1991. Forest Reindeer Herding A.D. I - 1800: an Archaeological and Palaeoecological Study in Northern Sweden. Archaeology \& Environment. Vol. 10. Umeå.

Axmann, see Bergsland 1943.

Bergsland, K. 1943 [1992]. Røros-samiske tekster. Norsk folkemuseum. Samiske samlinger. Vol. 17. Oslo. Bergsland, K. 1995[?]. Bidrag til sydsamenes historie. Senter for samiske studier. Skriftserie. Vol. 1.

Tromsø.

Brightman, R. A. 1993. Grateful Prey-Rock Cree Human-Animal Relationships. Oxford. van den Brink, P. \& Vikman, P.- $\AA$. 2000. Vegetationsförändringar på fjällen $i$ västra Härjedalen: fältinventering. Fjällforskningsinstitutet rapport 2000:3. Östersund.

Burström, M. 1999. Cultural Diversity in the Home Ground. How Archaeology can Make the World a Better Place. Current Swedish Archaeology. Vol. 7. Pp. 21-28.

Childe, V. G. 1942 [1946]. What happened in history? New York.

Clifford, J. 1998. Partial Truths. In: Clifford, J. \& Marcus, G. (Eds). Writing Culture: the Poetics and Politics of Ethnography. Pp. 1-26. Berkeley.

Cruikshank, J. 1998. Life Lived Like a Story: Life Stories of Three Yukon Elders. University of Nebraska Press.

DN 1995. Dagens Nyheter July 21, 1995. Renskötsel förstör svenska fjällen.

Danell, Ö. 1998. Renbete - ekologi och ekonomi. In: Olsson, O., Rolén, M. \& Torp, E. (Eds). Hållbar utveckling och biologisk mångfald i fjällregionen. Forskningsrådsnämnden/Fjällforskningsinstitutet. Pp. 193-205. Stockholm/Östersund.

Danielsen, I. E. Gåebrien sijte, Brekken, Sør-Trøndelag, Norway. Personal communication.

Danielsen, J. Svahken sijte, Gutu, Hedmark, Norway. Personal communication.

Danielsen, L. I. Svahken sijte, Gutu, Hedmark, Norway. Personal communication.

Drake, S. 1979 [1918]. Västerbottenslapparna under förra hälften av 1800-talet. Umeå [Uppsala].

Ekman, S. 1910 [1983]. Norrlands jakt och fiske. Uppsala [Umeå].

Falkenberg, J. 1985. Fra nomadisme til fast bosetning blant samene i Røros-traktene: 1890-åerne - 1940ărene. Aarjel-saemieh/Samer i sør. Vol. 2. Saemien sijte. Pp. 7-28. Snåsa.

Fellman, I. 1910. Handlingar och uppsatser angående finska lappmarken och lapparne. Helsingfors.

Fjellheim, S. 1991. Kulturell kompetanse og områdetilhorighet. Metoder prinsipper og prosesser i samisk kulturminnevernarbeid. Saemien sijte. Snåsa.

Fjellheim, S. 1999. Samer i Rørostraktene. Snåsa.

Fälthandbok: dokumentation av kulturlämningar för fornminnesregistret. 1997. Riksantikvarieämbetet. Kunskapsavdelningen, enheten för dokumentation. Stockholm. 
Fölster, S., Creydt, M., Österlind, C., Henrekson, M. \& Öhman, H. 2000. Rapport från analysgruppen: Tillväxtfaktorer. Svenska rese- och turistindustrins samarbetsorganisation. Stockholm.

Gren, L. 2000. Surveying the cultural heritage of the Swedish countryside: success and failure during the twentieth century. Current Swedish Archaeology. Vol. 8. Pp. 51-66.

Haarstad, K. 1992. Sørsamisk historie: ekspansjon og konflikter i Rorostraktene 1630-1900. Trondheim. Henriksson, H. 1978. Popular Hunting and Trapping in Norrland. Early Norrland. Vol. 6. Stockholm.

Hultkrantz, $\AA .1985$. Reindeer nomadism and the religion of the Saamis. In: Bäckman, L. \& Hultkrantz, $\AA$. (Eds.) Saami pre-christian religion: studies in the oldest traces of religion among the Saamis. Pp. 11-28. Stockholm.

Ihse, M. et al. 1998. Vegetationsslitage i fjällen. In: Olsson, O., Rolén, M. \& Torp, E. (Eds). Hållbar utveckling och biologisk mångfald i fjällregionen. Forskningsrådsnämnden/Fjällforskningsinstitutet. Pp. 170-183. Stockholm/Östersund.

Ingold, T. 1986. The Appropriation of Nature: Essays on Human Ecology and Social Relations. Manchester. Ingold, T. 2000. The Perception of the Environment: Essays in Livelihood, Dwelling and Skill. London.

Johansson, O. 1998. Rennäringens biologiska villkor beror även av de sociala villkoren. In: Olsson, O., Rolén, M. \& Torp, E. (Eds). Hållbar utveckling och biologisk mångfald i fjällregionen. Forskningsrådsnämnden/Fjällforskningsinstitutet. Pp. 76-78. Stockholm/Östersund.

Jordhøy, P. 2001. Snøhettareinen. Lesja.

Kjellström, R. 1983. Lappmarksmikroskop: intensivinventering av kulturlämningar i Jokkmokksfjällen. Nordiska museet. Stockholm.

Kjellström, R. 1995. Jakt och fängst $i$ södra Lappland i äldre tid. Stockholm.

Korhonen, O. 2000. Äldre samiskt bruk av tallens innerbark. In: Svanberg, l. \& Tunón, H. (Eds). Samisk etnobiologi: människor, djur och växter i norr. Pp. 266-280. Nora.

Krupnik, I. 1993. Arctic Adaptations: Native Whalers and Reindeer Herders of Northern Eurasia. London. Krupnik, I. 2000. Reindeer pastoralism in modern Siberia: research and survival during the time of crash. Polar Research. Vol. 19. Pp. 49-56.

Kvenangen, P. G. 1996. Samernas historia. Jokkmokk.

Liavik, K. 1999. Økologiske forhold på sommerboplassene i Mahkalahke og Tjerrålia. In: Fjellheim, S. (Ed). Samer i Rørostraktene. Pp. 149-169. Snåsa.

Lindkjølen, H. 1994. Johannes Schefferus og bokverket "Lapponia" utgitt 1673. In: Festskrift til Ørmulv Vorren. Tromsø museums skrifter 25. Pp. 23-35. Tromsø.

Linnér, K. 1989a. Samiska kulturlämningar. Riksantikvarieämbetet. Stockholm.

Linnér, K. 1989b. Fornlämningar i fångstmiljö: fjällinventering i W och Z län. Arkeologi i Sverige 1986. Riksantikvarieämbetet. Pp. 193-203. Stockholm.

Linnér, K. 1990. Rapport angående specialinventering av samiska kulturlämningar i nord-västra delen av Idre socken år 1989. Riksantikvarieämbetet. Stockholm.

Linnér, K. 1993. Fornlämningar på hög nivå: södra fjällvärldens fångstkultur. Arkeologi i Sverige. Vol. 2. Riksantikvarieämbetet. Pp. 195-235. Stockholm.

Lundmark, L. 1986. Äldre renskötsel - terminologi och tolkningar. Oknytt. Vol. 3-4. Pp. 52-61.

Lundmark, L. 1998. Så länge vi har marker: samerna och staten under 600 år. Stockholm.

Manker, E. 1945. Lapparna i Idre. In: Björk, E., Hilde, G. \& Söderlund, P. O. (Eds). Särna-Idre 300 år: en hembygdsbok. Pp. 171-190. Särna.

Manker, E. 1950. Fjällvärlden som kulturlandskap: några anteckningar från Nordiska museets och landsantikvariernas lappmarksundersökningar. Till fjälls. Svenska fjällklubbens årsbok 1950.

Manker, E. 1957. Lapparnas heliga ställen. Acta Lapponica. Vol. 13. Stockholm.

Myrhaug, M.-L. 1997. I modergudinnens fotspor: samisk religion med vekt på kvinnelige kultutøvere og gudinnekult. Oslo.

NM 1943, Nordiska museets lappmarksinventering, 1943. Idre sameby, Idre, Dalarna. Olof Andersson's gåetie at Hävlingskällorna. Drawing by Olle Homman. June 16, 1943. Stockholm.

Nielsen, Y. 1891. Lappernes fremrykning mot syd i Trondhjems stift og Hedemarkens amt. Det Norske Geografiske Selskabs Aarbog 1, 1889-1890. Kristiania.

Niklasson, M. 1996. Bark som människoföda ur agrart och samiskt perspektiv. In: Liljewall, B. (Ed). 
Tjära, barkbröd och vildhonung: utmarkens människor och mångsidiga resurser: Nordiska museet. Skrifter om skogs- och lantbrukshistoria. Vol. 9. Pp. 107-125. Stockholm.

Nuttall, M. 1998. Protecting the Arctic: Indigenous Peoples and Cultural Survival. Amsterdam.

Oksanen, L. 1998. Naturförhållanden och dynamik inom den fennoskandiska fjäll- och tundravärlden.

In: Olsson, O., Rolén, M. \& Torp, E. (Eds). Hållbar utveckling och biologisk mångfald ifjällregionen. Forskningsrădsnämnden/Fjällfforskningsinstitutet. Pp. 123-159. Stockholm/Östersund.

Olsson, G. A. 1996. Orörd vildmark eller fjällets kulturlandskap: biodiversitetsproblematik i norska fjällomrăden. In: Langaas, A. E. (Ed). Innfallsvinkler på biodiversitet: rapport fra flerfagligt workshop 7 desember 1995. Trondheim.

Pettersson, O. P. 1979. Kristoffer Sjulssons minnen: om vapstenlapparna i början av 1800-talet. Acta Lapponica. Vol. 20. Stockholm.

Päiviö, N. J., 2000. Lappskattelanden i Jukkasjärvi och deras utveckling. Sámi instituhtta. Diedut 2000:1. Guovdageaidnu.

Qvigstad, I. 1903. Det kongelige norske videnskabers selskabs skrifter 1903. Kildeskrifter til den lappiske mythologi. Trondheim.

Qvigstad, J. 1926. Lappsiche Opfersteine und heilige Berge in Norwegen. Oslo etnografiske museums skrifter. Vol. 1:5. Oslo.

RHIS Reindeer husbandry in Sweden [Svensk rennäring], 1999. Stockholm.

Reuterskiöld, E. 1910. Bidrag till vår odlings häfder. Källskrifter till lapparnas mytologi. Stockholm.

Ruong, 1. 1971. Samerna. Stockholm.

Rydving, H. 1993. The end of drum-time: religious change among the Lule Saami 1670s - 1740s. AUU.

Historia Religionum 12. Uppsala.

Rydving, H. 1995. Samisk religionshistoria: några källkritiska problem. Religionshistoriska forskningsrapporter från Uppsala 4. Uppsala.

SOU Statens offentliga utredningar 199:25 Samerna - ett ursprungsfolk i Sverige.

Schanche, A. 2000. Graver i ur og berg: samisk gravskikk og religion fra forhistorisk til nyere tid. Karasjok.

Sjulsson, see Pettersson

Svanberg, I. 1981. Sockenlappar. Rig. Vol. 69. Pp. 97-118.

Svanberg, I. 1999. Hästslaktare och korgmakare: resursutnyttjande och livsstil bland sockenlappar. Umeå. Sveen, K., 1985. Samisk kulturprosjekt i Engerdal. Aarjel-saemieh/Samer i sør. Vol. 2. Pp. 29-41. Snåsa.

Sveen, K., 1989. Rapport: registrering av samiske kulturminner, Engerdal 1982-85. Konservatoren for Trysil-Engerdal-regionen. Elverum.

Tanner, A., 1979. Bringing Home Animals: Religious Ideology and Mode of Production of the Mistassini Cree Hunters. London.

Thomasdotter, see Drake

Torp, E. 2001. Renar, rovdjur och retorik. Paper presented at Gaaltije, Östersund, Nov. 6, 2001.

Wallin, J.-E. \& Aronsson, K.-A. 1998. Mittåkläppen - markanvändning och vegetationsförändringar under två årtusenden. In: Anttila, S. \& Vikman, P.-Å. (Eds). Forskning och förvaltning för hållbar utveckling i landets fjällområden. Fjällforskningsinstitutet rapport 1998:2. Pp. 183-195. Östersund.

Warenberg, K., Danell, Ö., Gaare, E., \& Nieminen, M. 1997. Flora i renbetesland. Stockholm.

Wennstedt, B. 1989. Kultplatser i Övre Norrlands kustland. Oknytt. Vol. 3-4. Pp. 25-34.

Wennstedt Edvinger, B. 2000. Aspekter på sydsamiska björnceremonier. Fjällforskningsinstitutet FFI Forum 00:1. Östersund.

Wennstedt Edvinger, B., \& Winka, U. S. 2001. Sydsamiska kulturmiljöer. Skrifter utgivna av Gaaltije. Vol. 1. Östersund.

Wenzel, G. 1991. Animal Rights, Human Rights: Ecology, Economy and Ideology in the Canadian Arctic. London.

Wiklund, K.B. 1897-1905. Svenska landsmål och svenskt folkliv 17:4. Uppsala.

Zachrisson, I. \& Iregren, E. 1974. Lappish bear graves in northern Sweden. Early Norrland. Vol. 5. Stockholm.

Åhrén, I. 1988. Det samiska rummet. Aarjel-saemieh/Samer i sør. Vol. 3. Pp. 117-122. Snåsa.

Åhrén, I. 1998. Samiska kulturmiljöer - inventering och dokumentation. Gaaltije. Östersund. 